\title{
Preliminary Studies Regarding the Selection of Species and Types of Pot and Container for Vegetable Growing
}

\author{
Mirabela GACHE (LUNGU)*, Neculai MUNTEANU, Vasile STOLERU, Gabriel TELIBAN, Carmen CABA \\ (INCULEŢ)
}

University of Agricultural Science and Veterinary Medicine of Iasi, Faculty of Horticulture, Departament of Legumiculture, 3 Mihail Sadoveanu Alley, 700490 Iasi, Romania

*corresponding author: mirabelagache@yahoo.com

BulletinUASVM Horticulture 76(1) / 2019

Print ISSN 1843-5254, Electronic ISSN 1843-5394

DOI:10.15835/buasvmcn-hort: 2018.0041

\begin{abstract}
The purpose of the research reported in this paper was to evaluate the possibility of growing vegetable plants in pots and containers by optimizing the choice of species and cultivars and the type of pot or container based on the information available in the literature and on the basis of our own experience. Taking into account the purpose and objectives of this paper, the study is structured to respond to each objective considered. Information on crops in pot and containers shows that if the climatic conditions necessary for growth and development are optimal, basically any vegetable species can be grown in this system (Purnell, 2007). Concerning the pots in which vegetable plants can be grown, they are diverse and may be chosen specifically for this type of culture or can be assigned to provide the space necessary for plant growth for different species.
\end{abstract}

Keywords: crop, containers, pots, vegetable species

\section{Introduction}

The importance of growing vegetables in pots and containers derives from the need to use space efficiently and spend time pleasantly and comfortably (Camberato and Lopez, 2010). It has been said, with certainty that man was and it is attracted to nature forever. Not many are those who cultivate their vegetable plants in pots and containers, being in the company of nature, of beauty, either in the restricted space of living quarters or in the gardens (Rosario, 1986).

\section{Material and method}

The research was carried out in the experimental field of Faculty of Horticulture in Iasi, "V. Adamachi" farm, between April and October 2017. The experience has been set up with biological material consisting of seeds and seedlings of several species categories, with different plant size and vegetation period, cultivation technology and their annual/perennial character. The species used were: cherry tomatoes - Lycopersicon esculentum Mill. (Aristan Purple cv.), pepper - Capsicum annuum L. (Brilliant cv.), bean - Phaseolus vulgaris L. convar. communis (Aurie de Bacau cv.), lovage - Levisticum officinale Koch (cv. Communis), oregano - Origanum vulgare (Italian cv.), hot ornamental pepper - Capsicum annuum L. (Medusa cv.), lettuce - Lactuca sativa L. (Lollo bionda cv.), parsley - Petroselium crispum Mill. (Mohafodrozatu cv.), basil - Ocimum basilicum L. (Aristotle cv.), Phaseolus vulgaris convar oyster bean Nanus (Unidor cv.), dill - Anethum graveolens L. (Common cv.) and thyme - Satureja hortensis L. (Thymian cv.). The growing pots were of different sizes and were categorized as containers those of $60(\mathrm{~K})$ liters and $25(\mathrm{~K})$ liters and pots those of 5(P) liters and 2.5(P) liters (Guerra, 2005). 
The experimental versions studied with the described species and pots are presented in Table 1.

Pots were filled with a suitable crop substrate, formed from garden soil, peat, organic compost, sand and perlite (Pipa, 2008). The substrate was compressed to provide an adequate balance between the solid, liquid and gaseous phases. Some of the seeds as bean, parsley and dill were sown directly into the pots while from the other species seedlings were obtained and later planted into the pots or containers.

The set up period of the experiment has been chosen according to the weather conditions, so that the plants were not affected by inadequate low temperatures. In the first stage salad, dill, oregano, lovage and parsley were sown, and in second one tomato, sweet peppers, basil, thyme and beans (runner and dwarf). Seedlings have been produced in the greenhouse and thinned when they reached the development phase recommended in specialty literature (Stan and Munteanu, 2003).

Biometric determinations, phenology and productivity of the vegetable plants were carried out during the research. The experimental data were processed by statistical and mathematical methods using Excel program.

\section{Results and discussions}

The results are structured on certain major directions, related to the phenological, morphological and agroproductive characterization of the vegetable plants used.

The importance of the phenological characters is given precisely by the traits of the vegetable plants in the conditions of experimental cultivation, namely in pots and containers. Phenology of crops grown in pots and containers is expressed by several characteristics related to the main stages of growth as emergence, seedling thinning, duration of the vegetation and decorative period and/or maturation.

The phenological characters provide some important information on the evolution of vegetable plants in pots and containers during their growth and development. Knowing plant biology, this crop technology can easily be developed. Thus, the emergence of the vegetable plants in container crop lasts generally between 5-13 days, the number of days until thinning being an average of 1020 days (Tab. 2).

The decoration period was considered while a plant has decorative value through habitus, foliage, flowers and immature or mature fruits. This period varied within significant limits for the

Table 1. Vegetable plants and pot and container types

\begin{tabular}{|c|c|c|c|c|c|}
\hline \multicolumn{3}{|c|}{ Experiment 1} & \multicolumn{3}{|c|}{ Experiment 2} \\
\hline Vegetable sp. & $\begin{array}{c}\text { Pots } \\
\text { capacity (liters) }\end{array}$ & $\begin{array}{l}\text { No. of } \\
\text { plants }\end{array}$ & Vegetable sp. & $\begin{array}{l}\text { Pots capacity } \\
\text { (liters) }\end{array}$ & $\begin{array}{l}\text { No. of } \\
\text { plants }\end{array}$ \\
\hline \multirow{2}{*}{ Cherry tomato } & 25 & 1 & \multirow{2}{*}{ Hot ornamental pepper } & 5 & 1 \\
\hline & 60 & 3 & & 2.5 & 1 \\
\hline \multirow{2}{*}{ Pepper } & 25 & 1 & \multirow{2}{*}{ Basil } & 5 & 1 \\
\hline & 60 & 3 & & 2.5 & 1 \\
\hline \multirow{2}{*}{ Runner beans } & 25 & 1 & \multirow{2}{*}{ Salad } & 5 & 1 \\
\hline & 60 & 3 & & 2.5 & 1 \\
\hline \multirow{2}{*}{ Dwarf beans } & 25 & 1 & \multirow{2}{*}{ Parsley (leaves) } & 5 & 1 \\
\hline & 60 & 3 & & 2.5 & 1 \\
\hline \multirow{2}{*}{ Oregano } & 25 & 1 & \multirow{2}{*}{ Dill } & 5 & 1 \\
\hline & 60 & 3 & & 2.5 & 1 \\
\hline \multirow{2}{*}{ Lovage } & 25 & 1 & \multirow{2}{*}{ Thyme } & 5 & 1 \\
\hline & 60 & 3 & & 2.5 & 1 \\
\hline
\end{tabular}


Table 2. Phenological characterization of vegetable crops grown in containers

\begin{tabular}{lcccc}
\hline Species & $\begin{array}{c}\text { No. days till } \\
\text { emergence } \\
\text { (in greenhouse) }\end{array}$ & $\begin{array}{c}\text { No. days until } \\
\text { thinning }\end{array}$ & $\begin{array}{c}\text { No. days } \\
\text { decoration } \\
\text { period }\end{array}$ & $\begin{array}{c}\text { No. days until the } \\
\text { end of the growing } \\
\text { season }\end{array}$ \\
\hline Cherry tomato & 7 & 20 & 165 & 170 \\
\hline Pepper & 11 & 10 & 160 & 170 \\
\hline Oregano & 10 & 15 & 175 & 180 \\
\hline Lovage & 8 & 15 & 175 & 180 \\
\hline Runner bean & - & - & 165 & 170 \\
\hline Dwarf bean & - & - & 150 & 160 \\
\hline
\end{tabular}

Table 3. Phenological characterization of crops grown in pots

\begin{tabular}{|c|c|c|c|c|}
\hline Species & $\begin{array}{l}\text { No. days till emergence } \\
\text { in greenhouse }(\text { germination } \\
\left.\text { temperature } 18-20^{\circ} \mathrm{C}\right)\end{array}$ & $\begin{array}{l}\text { No. days } \\
\text { until } \\
\text { thinning }\end{array}$ & $\begin{array}{l}\text { No. days } \\
\text { decoration } \\
\text { period }\end{array}$ & $\begin{array}{l}\text { No. days until } \\
\text { the end of } \\
\text { the growing } \\
\text { season }\end{array}$ \\
\hline Basil & 10 & 15 & 155 & 165 \\
\hline Sweet pepper & 13 & 7 & 160 & 180 \\
\hline Salad & 5 & 8 & 38 & 38 \\
\hline Thyme & 10 & 7 & 175 & 180 \\
\hline Dill & - & - & 40 & 55 \\
\hline Parsley (leaves) & - & - & 165 & 180 \\
\hline
\end{tabular}

Table 4. Experimental crop production in pots and containers

\begin{tabular}{|c|c|c|c|c|c|}
\hline \multicolumn{3}{|c|}{ Experiment 1} & \multicolumn{3}{|c|}{ Experiment 2} \\
\hline Species & $\begin{array}{l}\text { Pot capacity } \\
\text { (liters) }\end{array}$ & $\begin{array}{c}\text { Total yield } \\
\text { (g) }\end{array}$ & Species & $\begin{array}{l}\text { Pot capacity } \\
\text { (liters) }\end{array}$ & $\begin{array}{c}\text { Total yield } \\
\text { (g) }\end{array}$ \\
\hline \multirow{2}{*}{ Cherry tomato } & 25 & 944,0 & \multirow{2}{*}{ Sweet pepper } & 5 & 508,8 \\
\hline & 60 & 1184,0 & & 2,5 & 391,5 \\
\hline \multirow{2}{*}{ Pepper } & 25 & 1289,0 & \multirow{2}{*}{ Basil } & 5 & 44,2 \\
\hline & 60 & 1016,9 & & 2,5 & 25,8 \\
\hline \multirow{2}{*}{ Runner been } & 25 & 850,8 & \multirow{2}{*}{ Salad } & 5 & 151,8 \\
\hline & 60 & 1002,0 & & 2,5 & 95,1 \\
\hline \multirow{2}{*}{ Dwarf been } & 25 & 1073,6 & \multirow[t]{2}{*}{ Parsley } & 5 & 83,37 \\
\hline & 60 & 1981,0 & & 2,5 & 66,58 \\
\hline \multirow{2}{*}{ Oregano } & 25 & 183,2 & \multirow{2}{*}{ Dill } & 5 & 90,4 \\
\hline & 60 & 94,4 & & 2,5 & 82,6 \\
\hline \multirow{2}{*}{ Lovage } & 25 & 221,1 & \multirow{2}{*}{ Thyme } & 5 & 95,4 \\
\hline & 60 & 407,3 & & 2,5 & 88,6 \\
\hline
\end{tabular}




\section{Cherry tomato}

Type of pot
Height
No. inflorescences
No. fruits/plant
Average fruit weight
Total yield/plant

\section{Runner bean}

Type of pot
Height
No. inflorescences
No. pods/plant
Average pod weight
Total yield/plant

Oregano

$$
\begin{gathered}
\text { K } 60 \mathrm{~L}-\mathrm{K} 25 \mathrm{~L} \\
1.7 \mathrm{~m}-1.5 \mathrm{~m} \\
9.0-9.0 \\
36.0-34.0 \\
21.0 \mathrm{~g}-18.5 \mathrm{~g} \\
1184.0 \mathrm{~g}-944.0 \mathrm{~g}
\end{gathered}
$$

\section{Pepper}

Type of pot

K 60 L - K25 L

Height

No. inflorescences

$0.8 \mathrm{~m}-0.8 \mathrm{~m}$

$14-13$

No. fruits/plant

$14.0-13.0$

Average fruit weight

$78.3 \mathrm{~g}-88.5 \mathrm{~g}$

Total yield/plant

\section{Dwarf bean}

Type of pot

Height

No. inflorescences

No. pods/plant

Average pod weight

Total yield/plant
K 60 L - K 25 L

$$
0.7 \text { m - } 0.7 \text { m }
$$$$
8 \text { - } 8
$$$$
77.0-79.0
$$$$
11.5 \mathrm{~g}-10.5 \mathrm{~g}
$$

1188.6 - $1073.6 \mathrm{~g}$

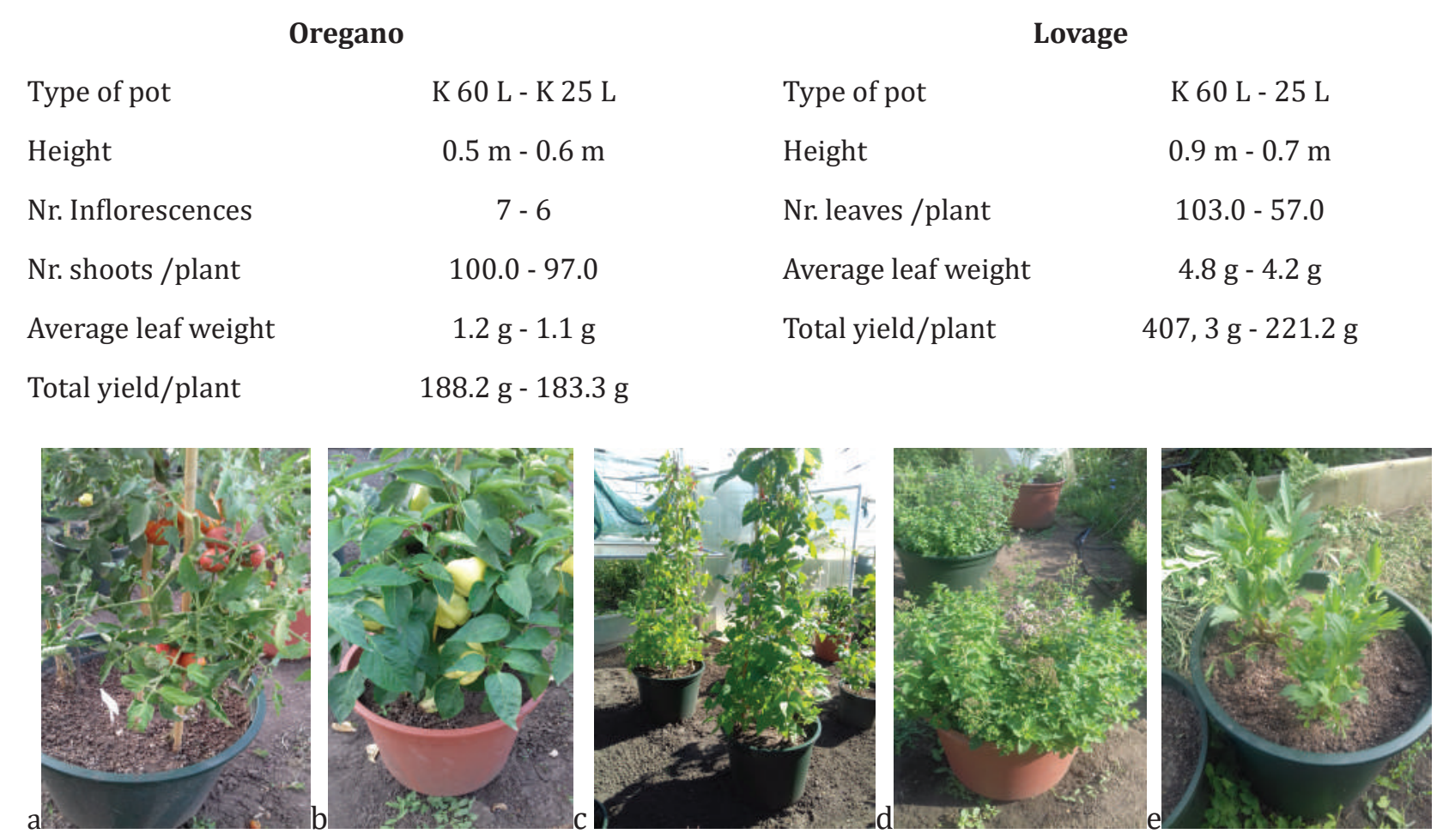

Figure 1. Vegetable plants grown in containers a. Cherry tomatoes, Ariston Purple cv. ; b. Pepper, Brilliant cv.; c. Runner bean , Aurie de Bacau cv.; d. Oregano, Italian cv.; e. Lovage, Communis cv. (original photo) 


\section{Sweet pepper}

Basil

Type of pot

Height

No. inflorescences

No. fruits/plant

Average fruit weight

Total yield/plant

\section{Parsley}

Type of pot

Height

No. leaves/plant

Average leaf weight

Total yield/plant

Dill

Type of pot

No. leaf rosette/plant

Average leaf weight

Total yield/plant
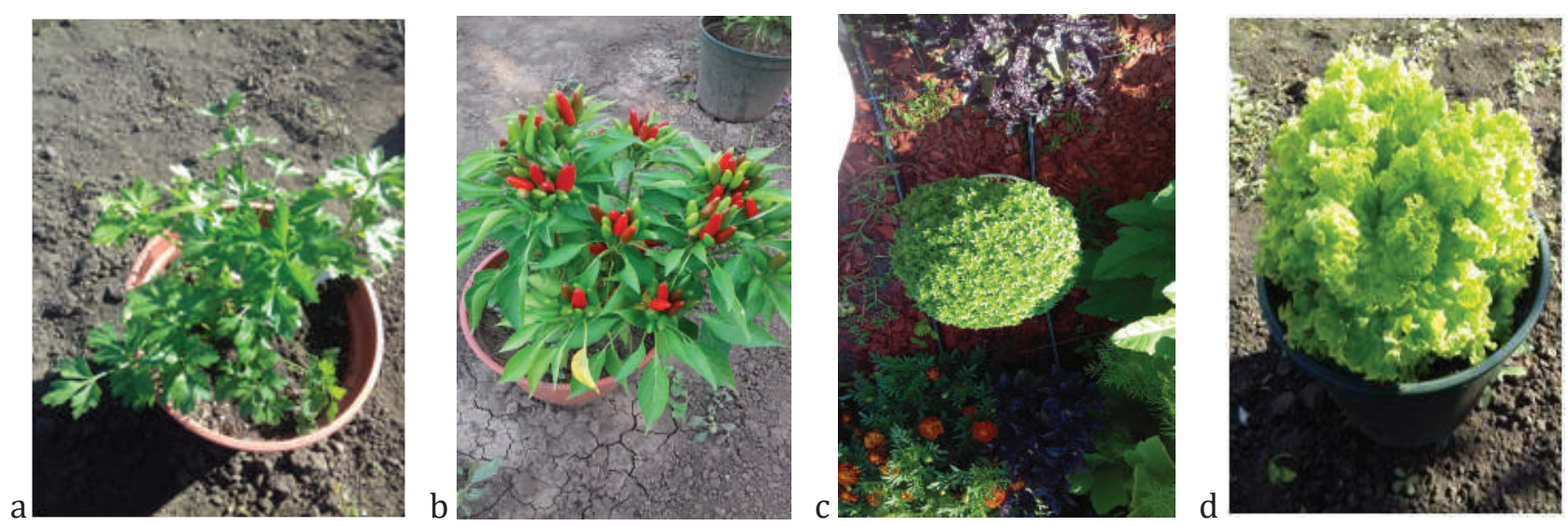

G 5 L - G 2.5 L

$0.6 \mathrm{~m}-0.4 \mathrm{~m}$

$20-15$

$25.0-15.0$

$1.0 \mathrm{~g}-0.9 \mathrm{~g}$

$22.1 \mathrm{~g}-13.0 \mathrm{~g}$
Salad

Type of pot

G $5 \mathrm{~L}-\mathrm{G} \mathrm{2,5} \mathrm{L}$

Nr. leaves/ plant

$21.0-16.0$

Average leaf weight

$2.4 \mathrm{~g}-2.9 \mathrm{~g}$

Total head weight

$151.8 \mathrm{~g}-95.1 \mathrm{~g}$
Thyme

Type of pot

G 5 L - G $2.5 \mathrm{~L}$

$69.0-57.0$

$1.2 \mathrm{~g}-0.9 \mathrm{~g}$

$95.4 \mathrm{~g}-88.6 \mathrm{~g}$

Figure 2. Vegetable plants grown in pots

a. Parsley, Mohafodrozatu cv; b. Hot pepper, Medusa cv;

c. Basil, Aristotle cv; d. Lettuce, Lollo Bionda cv. (original photo) 
potted species, ranging from 38 to 175 days (Tab. 3).

The end of the vegetation period is marked by the optimum harvest time (lettuce), the maturity of the fruit on the plant and the appearance of the first frost. This period ranged from 38 days to 180 days (Tab. 3).

The morphological study of plants grown on pots and containers was observed in a comparative trial, in all development phases. Thus, the main features considered in the experiment were: plant height, number of inflorescences, number of harvested fruits/number of harvested shoots, weight of fresh leaf/average fruit weight.

Yield of the vegetable plants under study has emphasized some specific characters concerning their productive potential under the conditions of pot and container cultivation.

\section{Conclusion}

Growing of vegetable plants in pots and containers is suitable for the studied species.

The morphological characterization of vegetable plants grown in pots and containers emphasizes the fact that they fit the botanical description of these species thus, in the experimental conditions presented, the ecological requirements of the plants have been propitious, which allowed proper growth and development.
The phenological observations revealed that all the phenophases were accomplished according to the optimal ontogenetic evolution of each studied species, which allows us to conclude that the vegetable plants cultivated in pots and containers in our experiment have found favorable conditions for growth and development.

Acknowledgments. This research did not receive any specific grant from funding agencies in the public, commercial, or not-for-profit sectors.

\section{References}

1. Camberato D and Lopez R (2010). Biocontainers for LongTerm Crops, GreenhouseGrower.com.

2. Guerra M (2005) The edible container garden: Fresh food from tiny spaces. Gaia Books Ltd.

3. Munteanu N (1987) "Aurie de Bacău" - un nou soi de fasole de grădină. Producția vegetală, Horticultură, 1.

4. Munteanu N (2003). Tomatele, ardeii şi pătlăgelele vinete. Ed. "Ion Ionescu de la Brad", Iaşi.

5. Pipa G (2008). 1001 de idei pentru grădina ta. Ed. Allfa, Bucureşti.

6. Purnell B (2007). Crops in pots. Readers Digest.

7. Rosario A (1986). Peisajul şi estetica, Ed. Meridiane, București.

8. Stan N and Munteanu N (2003). Legumicultură, vol. III. Editura „Ion Ionescu de la Brad”, Iaşi. 